\title{
STUDY ON PROFESSORS' PERCEPTION ABOUT THE FACTORS OF DROPOUT AT AN INTEGRATED TECHNICAL BRAZILIAN SCHOOL
}

\author{
Cergio Roberto Veiga ${ }^{1}$; Nissia Carvalho Rosa Bergiante ${ }^{1^{*}}$ \\ 1 Universidade Federal Fluminense, 24210-253, Niterói-RJ, Brazil \\ *nissiabergiante@id.uff.br
}

Submitted at 19/02/2018 and accepted at 01/04/2018

\section{ABSTRACT}

The high rate of school dropout is the subject of debate and educational public policies. The PNUD-2013 report reveals that Brazil, compared to the 100 countries with the highest Human Development Index, presents a rate of $24.3 \%$ related to dropping out of school, ranking 85th. Due to this reality, school dropout has become a phenomenon by several researchers. This study sought to observe the teachers' perception of 04 technical courses about the school dropout rate at a federal public-school system. We applied a qualitative and quantitative
\end{abstract}

approach. In total, 12 coordinators / teachers of the courses were interviewed using data collection instrument. The results showed their current opinion about the occurrence of this phenomenon is that it is promoted as a function of the socioeconomic condition and cultural context in which the student is inserted. The data analysis indicates that the revitalization of the curriculum and the implementation of a school reinforcement system can effectively contribute to the mitigation of school dropout in the researched school.

\section{PERCEPÇÃO DOS DOCENTES SOBRE OS FATORES DA EVASÃO ESCOLAR NO ENSINO TÉCNICO INTEGRADO EM UMA INSTITUIÇÃO DE ENSINO BRASILEIRA}

\begin{abstract}
RESUMO
A elevada taxa de evasão escolar é o assunto em destaque nos debates e argumentações relativos às políticas públicas educacionais. O relatório PNUD-2013 revela que o Brasil, em comparação aos 100 países com maior Índice de Desenvolvimento Humano, apresenta uma taxa de $24,3 \%$ relativa ao abandono escolar, ocupando a $85^{\circ}$ posição no ranking. Em função dessa realidade, a evasão escolar tornou-se um fenômeno abordado por diversos pesquisadores. Este trabalho buscou observar a percepção dos docentes de 04 cursos técnicos a respeito da evasão escolar em uma escola da
\end{abstract}

rede pública federal de ensino. Utilizou-se uma abordagem qualitativa e quantitativa. Empregou-se como instrumento para coleta dos dados uma entrevista, de forma presencial, a 12 coordenadores/professores dos cursos. Os resultados apontaram que a ocorrência desse fenômeno é promovida em função da condição socioeconômica e cultural na qual o aluno está inserido. A análise dos dados evidencia que a revitalização do currículo vigente e a implementação de um sistema de reforço escolar podem contribuir efetivamente na amenização da evasão escolar no espaço pesquisado.

PALAVRAS CHAVE: escola técnica federal; evasão escolar; docentes 


\section{INTRODUCTION}

Data from the School Census (Brazil, 2014) provided by the National Institute of Studies and Research Anísio Teixeira (INEP), show that more than 1.3 million children and adolescents throughout Brazil left the classrooms during the 2013 school year. Complementarily, the United Nations Development Program (PNUD) 2014 reveals that one in four students who begin elementary school in Brazil have left school before completing the last series (PNUD, 2014).

The national scenario becomes even more complex when observing the PNUD-2014 report, which reveals that, compared to the 100 countries with the highest Human Development Index, Brazil has a dropout rate of $24.3 \%$ being ranked in the $85^{\text {th }}$ position among all countries in the list.

Due to this reality, not only in Brazil but in many other countries, school dropout has become a phenomenon analyzed and discussed by several researchers who seek to contribute to the solution of this problem ( GARCIA et al. (2017), GOTTFRIED \& PLASTER (2017), LANSFORD 2016), LIMA ET AL. (2016), SANTOS ET AL. (2016), BARRETO ET AL (2017)) .

For Batista and Oliveira (2009) school dropout is composed of diversified parameters that act mutually within this problematic. The authors emphasize that the decision taken by the person to leave school is influenced by socioeconomic, cultural, educational, historical and social dimensions, among others. In this context, Adeleke and Ogunkola (2013) discusses that school dropout brings severe limitations to future prospects, causing the deepening and uninterrupted cycle of poverty. Neri (2009) identified that $40 \%$ of 15-to 17-year-olds stop studying for the simple fact that they believe that school is uninteresting. Another factor, emphasized by Leon and Menezes-Filho (2002), that influences the young students of the High School in the decision to continue or not to study is the frequent disapprovals, inducing them to the disinterest and consequently to the school dropout.

Research on this topic points out different and complex causes for school failure, highlighting different variables that lead the student to avoidance. Ferreira (2013) corroborates that the reasons for school dropout do not act in isolation, since the occurrence of the phenomenon occurs due to the concomitance of different parameters.

In this context, this research will verify the teachers' perception of school dropout in 04 technical courses of a school part of the federal education system in Rio de Janeiro/Brazil, to understand if the practical experience corroborates the already mentioned factors in the literature, contributing in the search of answers to the problem of dropout in the Institution. Properly identification, analysis and understanding of the factors that influence the students in the school leaving process may contribute to bringing actions that may reduce this phenomenon.

This work is organized in four sections, namely: section two brings a conceptual approach on the subject, based on literature review. Section three describes the processes used in the methodology. Then, in section four, we analyze and interpret the results. And in the last section we discuss the conclusion.

\section{LITERATURE REVIEW}

The Federal Constitution of 1988 (BRASIL, 1988) brings forth in its Art. 205 that: "education, the right of all and the duty of the State and the family, shall be promoted and encouraged with the collaboration of society, aiming at the full development of person, their preparation for the exercise of citizenship and their qualification for work. " In this sense, education 
is in harmony with the exercise of constitutional law, guaranteeing to all citizens the expectation of intellectual acquisition for the benefit of themselves and of the nation.

In addition to the Magna Carta, the Law of Guidelines and Bases of Education (LDB 9394/96) emphasizes through Art. 2: "The education, duty of the family and the State, inspired by the principles of freedom and the ideals of human solidarity, aims at the full development of the student, his preparation for the exercise of citizenship and its qualification for work ". Thus, the immense task that is the task of the society and the State in the formation of the students is made evident, seeking, through education, the social insertion of the person.

The Statute of the Child and the Adolescent (BRASIL, 1990), describes, in its art. 4, that "it is the duty of the family, society in general, public power and the community to ensure the right to education of children and adolescents." From this article, it will be observed that the development, preparation for the exercise of citizenship and the professional qualification of the student will be consolidated among society, family, community and public power.

\subsection{School failure and dropout}

School failure is understood under several concepts, among others, it is possible to emphasize school dropout and repetition. According to Neri (2009), Aranha (2009), Souza (2011), Ferreira (2013), Jiménez Asenjo and Gaete Astica (2013), a diversity of causes can lead to school failure such as learning disabilities, lack of teaching knowledge, individual disinterest, drug involvement, pregnancy, necessity to work, etc. As Machado (2009) states, " deal with dropout is to deal with school failure; which presupposes a subject that did not achieve success in his or her school career "(MACHADO, 2009, 36). Thus, it is observed that school failure can be from cultural, social and political aspects, in which the individual may be involved in your everyday situation.

Some authors believe that evasion is a complex and multidimensional problem, and there is a need for more research on this phenomenon (AZEVEDO 2006; DORE and Lüscher, 2011; FERREIRA, 2013).

Asenjo and Astica (2013) point out that in order to obtain a thorough knowledge about dropout, it is important to analyze some relevant aspects related to family, institutional management and social and economic conditions. Adeleke and Ogunkola (2013) identified a large proportion of students being compelled to drop out of school. This initiative is not spontaneous, but rather due to its precarious financial condition that forces poor and younger people to be early inserted in the labor market.

Bastos (2014) points out that for a better understanding of this phenomenon, it is necessary to analyze the concepts of repetition, failure and dropout. Mendes (2013) maintains that of the varied factors inherent to avoidance, much of it is associated with the student's "motivation". According to the author, through the planning and structuring of pedagogical methods it is possible to do a well insertion of the student in the school. Barros et al. (2008) argues that it is up to the institution, through the planning and structuring of pedagogical methods, to fully support the student in the school universe. 


\subsection{Dropout rates in secondary vocational education}

Data shows that school dropout rate keeps increasing in the modality of vocational secondary education. This output is not welcome specially within a capitalist society where technical ability is a preponderant factor for the absorption of the individual in an increasingly demanding and exclusive world of work.

Araújo and Santos (2012) emphasize the expressive demand for a professional formation, facing the search of young people and adults for a quick placement in selective work market, as well as in a pursue for a better payroll. However, the authors point out how difficult it is for the student to remain in this educational model.

Kalleberg (2011) warns of changes in the workforce over the last 40 years. The author alerts that a student who drops out does not have the same opportunity to get a job as the students who left school in the 1970s or 1980s, because lack of qualification hinders access to the labor market, entailing a multitude of disadvantages.

According to data from the IPEA Social Perceptions Indicators System (SIPS), in 2011, in Brazil ,45\% of the unemployed were looking for work for more than six months and $25 \%$ more than a year (BRASIL, 2011). Data showed that this delayed reinsertion in the market was due to the lack of professional qualification.

In 2010, the researcher of the Center for Social Policies of the Getulio Vargas Foundation (FGV), Marcelo Neri, published the results of a survey based on data from the National Employment Survey (PNAD) and the Monthly Employment Survey (PME). The number of opportunities for young people who attend some form of professional education is $48 \%$ higher than for people without it, and the possibility of a formal contract also grows $38 \%$.

Severino and Dias (2013) argue that although the students of vocational education seek to enter the labor market by completing the course, the amount of dropout in this type of education is still significant. Therefore, it is essential to guide them, in the sense of making them realize, that through professional qualification the chances of employability are higher.

\subsection{National data on school dropout}

Data from the School Census (2014) revealed that by adding all stages of elementary education (initial, final and high school), more than 1.3 million children and adolescents throughout Brazil left the classrooms during the school year of 2013 (BRASIL, 2014).

Yet, the challenge is that in the last years of basic education, the student starts to be poised between studies and work. Watakabe (2015), in his research in technical courses at the Federal Institute of Paraná, Campus Paranavaí, concluded that entering the workforce means that students have less time to devote to school content, which contributes to increasing evasion.

In 2012, the dropout rate in Brazil (Table 1) reached 24.3\%. And the index becomes even more worrying when compared to neighboring countries, such as Chile (2.6\%), Argentina (6.2\%) and Uruguay (4.8\%). Of the 1.6 million elementary school leavers who dropped out last year, more than 1.5 million were enrolled in public schools, both at the fundamental level $(762,000)$ and the High School (760,000). 
Table 1: Income of education (2012)

\begin{tabular}{|c|c|c|c|c|}
\hline Parents & Ranking & IDH & $\begin{array}{c}\text { Population } \\
\text { (complete secondary } \\
\text { education) }\end{array}$ & $\begin{array}{c}\text { School dropout } \\
\text { rate }\end{array}$ \\
\hline Norway & $1 \mathrm{st}$ & 0.955 & $95.2 \%$ & $0.5 \%$ \\
\hline Australia & $2^{\text {o }}$ & 0.938 & $92.2 \%$ & Not informed \\
\hline U.S & 3 rd & 0.937 & $94.5 \%$ & $6.9 \%$ \\
\hline Netherlands & 4 th & 0.921 & $88.9 \%$ & Not informed \\
\hline Germany & 5 th & 0.920 & $96.5 \%$ & $4.4 \%$ \\
\hline Chile & 40 th & 0.819 & $74 \%$ & $6.2 \%$ \\
\hline Argentina & 45 th & 0.811 & $56 \%$ & $4.8 \%$ \\
\hline Uruguay & $51^{\circ}$ & 0.792 & $49.8 \%$ & $6 \%$ \\
\hline Mexico & $61 \mathrm{st}$ & 0.775 & $53.9 \%$ & $24.3 \%$ \\
\hline Brazil & 85 th & 0.730 & $49.5 \%$ & $2.6 \%$ \\
\hline
\end{tabular}

Source: PNUD / UN 2013

\subsection{The family issue}

According to Dore and Lüscher (2011), there is a difficulty of identifying the factors that cause dropout just because it can be associated to other processes related to school performance. The dropout rate can be affected by factors inherent to the student and his / her family, by the school institution and by the social environment in which it is inserted.

The research of Brandão et al. (1983), based on a sample of five Latin American countries, showed that the family is the most significant parameter in the student's academic life. The study revealed that the higher the level of education of the mother, the longer the student' stay, as well as the child's educational performance.

In recent research, Yi et al . (2015) consolidated the conclusion of Brandão et al. (1983), stating that the level of schooling of family members, especially that of the mother, encourages the child to seek a higher level of schooling. Thus, it is evident that the commitment of the family in the academic life of the children, behaves as a fundamental element in the fight against school failure.

\subsection{Reasons for school dropout}

This section presented data revealing the school failure as a complex phenomenon, regarding events or situations that provide the generative force that is its origin. Thus, it is necessary to carry out studies that can aggregate these conceptions, considering the different aspects involved in their construction. By understanding these distinct approaches we were able to define the basic constructs that will be used in our data collection form, applied to the teachers.

We summarize our findings in four constructs: Need to work; Students' lack of interest; Unattractive school, and Social inequality (Table 2). 
Table 2 - Summary of reasons for school dropout

\begin{tabular}{|c|c|c|c|c|}
\hline AUTHORS & $\begin{array}{l}\text { Need to } \\
\text { Work }\end{array}$ & $\begin{array}{c}\text { Student Lack } \\
\text { of Interest }\end{array}$ & $\begin{array}{c}\text { Unattractive } \\
\text { School }\end{array}$ & $\begin{array}{c}\text { Social } \\
\text { inequality }\end{array}$ \\
\hline Adeleke and Ogunkola (2013) & $\mathbf{x}$ & & & \\
\hline Aranha (2009) & & $\mathbf{x}$ & & \\
\hline Araújo and Santos (2012) & & & $\mathbf{x}$ & \\
\hline Azevedo (2006) & & & $\mathbf{x}$ & \\
\hline Barros, et al.(2008) & & $\mathbf{x}$ & & \\
\hline Bastos (2014) & & $\mathbf{x}$ & & \\
\hline Ferreira (2013) & $\mathbf{x}$ & & & \\
\hline Mendes (2013) & & $\mathbf{x}$ & & \\
\hline Neri (2009) & & $\mathbf{x}$ & & \\
\hline Neri, (2010) & & & & $\mathbf{x}$ \\
\hline Souza (2011) & & & & $\mathbf{x}$ \\
\hline Watakabe (2015) & $\mathbf{x}$ & & & \\
\hline TOTAL (\%) & 25 & 41.6 & 16.7 & 16.7 \\
\hline
\end{tabular}

Source: Authors

Through the analysis of Table 2 , it can be confirmed that most researchers point out that "Student Disinterest" is the main reason for dropping out of school. This result is confirmed by the study carried out by Neri (2009), where it was found that $40 \%$ of young people between 15 and 17 years of age leave school because of lack of interest. Barros, et al . 2008 emphasizes that this demotivation is since the school does not offer what the youth seeks. The authors emphasize that a deep investigation is necessary, trying to find out the reason for the problem.

Another factor to consider is the need to work, which threatens the permanence of students in the school environment. As explained by Adeleke and Ogunkola (2013), who identified many students being forced to drop out of school, not because of their spontaneous nature, but rather due to their precarious financial condition.

It has been found that there is a relevance of extracurricular factors that influence the dropout process. Thus, we can see the interaction between the factors, which consequently lead the youth to school dropout, as verified by Araújo and Santos (2012).

\section{MATERIAL AND METHODS}

Marconi and Lakatos (2010, p.139) conceptualize research as a "systematic, controlled and critical reflex procedure that allows us to discover new facts or data, relationships or laws in any field of knowledge." For Gil (2010, p. 01), research is the "rational and systematic procedure that aims to provide answers to the problems that are proposed". In this way, the development of a research is established through methods and techniques of scientific research, aiming to solve the problems proposed. 
The present study used the types of exploratory and descriptive research, being the research carried out in a Public Integrated High School. As for the technical procedures, bibliographical reviews and interviews were used.

The interviews were applied in person to 12 teachers of the technical courses in electronics, buildings, mechanics and computers, with a duration of approximately 50 minutes. With their permission we recorded the interviews and transcribed all answers. Teachers answered a questionnaire with 06 questions that seek to know the perceptions, expectations and opinions of teachers on the main causes that lead students to leave their courses.

The inquiries followed a semi-structured script composed of four open questions and two elaborated using a Likert scale. Regarding the open questions, we approached: interference of the course choice in the dropout process, learning factor, curriculum adjustments to individual differences of the students and types of activities that can lead to students' motivation.

1. In your opinion, can orientation in choosing the course interfere with the dropout process? How?

2. What is your perception regarding the students' learning performance?

3. How do you evaluate the current school curriculum in meeting individual student differences?

\section{To what extend can teachers improve levels of motivation in the students?}

For the closed-type questions, we used Likert scale, with two objectives: first, verify the teachers' perceptions regarding the quality of some institutional parameters, namely: teacher attendance, technological resources, teaching quality and the physical infrastructure of the school (Figure 1). Second, classify what factors, in the opinion of teachers, among the list of options offered (Figure 2), would further influence the student's decision to evade.

\begin{tabular}{|l|l|l|l|l|l|l|}
\cline { 2 - 6 } \multicolumn{1}{c|}{} & \multicolumn{5}{c|}{ Evaluation of Institutional Parameters } \\
\cline { 2 - 6 } \multicolumn{1}{c|}{} & Poor & \multicolumn{1}{c|}{ Bad } & Reasonable & Very good & Great \\
\hline \multicolumn{1}{|c|}{ PARAMETERS } & \multicolumn{5}{|c|}{} \\
\hline Teachers' Assiduity & & & & & \\
\hline Technology Resources & & & & & \\
\hline Quality of teaching & & & & & \\
\hline School physical infrastructure & & & & & \\
\hline
\end{tabular}

Figure 1 - Evaluation of institutional parameters

Source: Authors

\begin{tabular}{|l|l|l|l|l|l|}
\cline { 2 - 5 } \multicolumn{1}{c|}{} & \multicolumn{5}{c|}{ DEGREE OF INFLUENCE } \\
\cline { 2 - 6 } \multicolumn{1}{c|}{} & $\begin{array}{c}\text { Very } \\
\text { Influential }\end{array}$ & $\begin{array}{c}\text { Average } \\
\text { Influence }\end{array}$ & $\begin{array}{c}\text { Weak } \\
\text { Influence }\end{array}$ & $\begin{array}{c}\text { Very Weak } \\
\text { Influence }\end{array}$ & $\begin{array}{c}\text { Influence } \\
\text { Insufficient }\end{array}$ \\
\hline Student Lack of Interest & & & & & \\
\hline Need to Work & & & & & \\
\hline Difficulties in learning & & & & & \\
\hline Lack of family support & & & & & \\
\hline Wrong course choice & & & & & \\
\hline Distance School x Residence & & & & & \\
\hline
\end{tabular}

Figure 2 - Predominant school dropout factors

Source: Authors 
The interview had the participation of twelve teachers belonging to six departments: buildings, electronics, electrotechnology, computer science, mechanics and work safety. In order to maintain anonymity, subjects will be arranged by alphanumeric codes, the sample being composed by:

- E1 - teacher EBTT (Technical-technological-basic teaching), belongs to the actual staff and holds a master's degree, teaching time in the institution between 15 and 25 years;

- E2 - professor EBTT, belongs to the effective staff and holds a degree in specialization, teaching time in the institution between 10 and 20 years;

- E3 - teacher EBTT, belongs to the effective staff and holds a master's degree, teaching time in the institution between 15 and 25 years;

- E4 - teacher EBTT, belongs to the effective staff and holds a degree in specialization, teaching time in the institution between 10 and 20 years;

- E5 - teacher EBTT, belongs to the effective staff and holds a degree in specialization, teaching time in the institution between 05 and 15 years;

- E6 - Senior Magisterium teacher, belongs to the effective staff and holds a doctorate degree, teaching time in the institution between 20 and 30 years;

- E7 - Professor of Higher Education, belongs to the actual staff and holds a doctorate degree, teaching time in the institution between 20 and 30 years;

- E8 - teacher EBTT, belongs to the effective staff and holds a master's degree, teaching time in the institution between 15 and 25 years;

- E9 - professor EBTT, belongs to the effective staff and holds a degree in specialization, teaching time in the institution between 10 and 20 years;

- E10 - professor EBTT, belongs to the actual staff and holds a doctorate degree, teaching time in the institution between 15 and 25 years;

- E11 - teacher EBTT, belongs to the actual staff and holds a master's degree, teaching time in the institution between 10 and 20 years;

- E12 - teacher EBTT, belongs to the actual staff and holds a degree in specialization, teaching time in the institution between 05 and 15 years.

The questions of the interview sought to understand the reality experienced by these professionals in the practice at the School, to know the teachers '/ coordinators' perception about the dropout process in each technical area and, with this, to apprehend the positioning of these professionals in face of this phenomenon.

\section{RESULTS}

In this section we will present the results of the interviews and their discussion considering the bibliographic research carried out in the section 2. As already specified in the methodology, the procedure was applied to 12 teachers/coordinators from different technical courses. The interviews lasted an average of 50 minutes, while, it was opportune to exchange ideas with the teachers about the activities applied in class, as well as their relationship with the students.

On the first block of closed questions (Figure 1) the answers allowed us to evaluate the assiduity of the teachers: $38 \%$ considered it reasonable; $25 \%$ as very good; $25 \%$ as excellent and $12 \%$ as bad. 
For technological resources, $33 \%$ said to be very good; $42 \%$ as reasonable, $12 \%$ as excellent and $13 \%$ as bad.

Regarding the quality of teaching, $29 \%$ think it is reasonable, while $36.5 \%$ say they are very good and $34.5 \%$ are excellent.

Regarding the physical infrastructure of the school, $25 \%$ of the teachers rated it as reasonable, while $58.3 \%$ considered it to be very good and $16.6 \%$ as bad.

Thus, in general, the teachers showed satisfaction with the institutional factors, being low the number of bad evaluations.

In the second block, regarding the predominant factors of school dropout, the most significant factor in the conception of $83.3 \%$ of the teachers was the student's own lack of interest. This was followed by learning difficulties $(75 \%)$; to the wrong choice of course $(66.6 \%)$.

Regarding the student's lack of interest and the mistaken choice of the course, we noticed from the teachers' responses that these factors are related. For $67 \%$ of teachers, the family influence is predominant: (E1) "The student is very young, comes to make the technician by family decision, without having the slightest notion of the course he chose"; (E3) "Many times the course is chosen by the parents"; (E5) "A classic example of family interference is observed in the computer course, where the candidate enrolls with the wrong conception that will be a good part of the class in front of the computer"; (E7) "Many young people end up choosing the course because of family pressure and not vocation"; (E8) "Most students make this choice without any guidance, being influenced by their family members"; (E9) "Guidance should be clear, without family interference"; (E10) "Orientation, without family intervention, is essential so that the expectations of the course are not frustrated"; (E11) "Most students make this choice without any guidance, suffering strong family influence."

As for the difficulties in learning, there is a great concern on the part of the teachers, since (E1) "Some students have a lot of difficulty, either because they lack basic knowledge or because they do not identify with the course"; (E4) "They arrive with great deficiency of elementary school, without a routine of study"; (E5) "Learning requires student commitment and depends on a mature and rational course choice"; (E6) "It is possible to notice that a great part of the students is very dispersed, which ends up disturbing the others"; (E7) "The classes are very heterogeneous. Some students have a hard time either because they do not have some basic knowledge or because they do not identify with the course or the school "; (E8) "Many are interested only in High School, not in the technical part"; (E9) "Some have deficiencies from elementary education, showing lack of preparation in subjects that require more reasoning like mathematics, physics and chemistry"; (E10) "Students today are poorly prepared, do not know fundamental concepts of physics, chemistry and mathematics."

Most teachers interviewed, $58.3 \%$, pointed out that the current school curriculum is out of date, failing to address individual differences among students. (E1) "Bad. I do not see this being applied "; (E3) "There is not much concern about it"; (E6) "Do not answer. Bad"; (E7) "The curriculum needs to be reviewed"; (E8) "It is necessary to draw up a curriculum that addresses diversities"; (E10) "I do not see anything that focuses on individual differences"; (E11) "We have to study a way to serve him/her [the student]."

It is noticeable in the analysis of the context that it is urgent to elaborate a curriculum that attends to the individual differences of the students, that allows the students, independent of their 
social reality, to really learn and that promotes stimuli so that they remain in the school until their graduation.

Regarding the parameter distance of school, the majority of teachers, $75 \%$, classified as weak influence. For the factor needing to work, all teachers interviewed, that is, $100 \%$ considered as insufficient influence.

Inquiring about the activities for students' motivation, an unanimity was observed saying that laboratory activities and technical visits can do the job. There are also those who invest in research projects, or in extended activity done in favor of the community, or teaching assistance and national competitions as alternative ways to stimulate students, especially those who had difficulties or are demotivated.

The interview allowed us to observe not only how these teachers understand the dropout but also, what is their involvement in the permanence of their students in the classroom. During the interviews, we noted the expression of teacher satisfaction in relation to students who achieved success academically, as well as professionally. Even with the current educational difficulties, they found themselves enjoying what they do, aware of their motivational role in their students' life, revealing this as a prime factor for school success.

By comparing the results of this study with data found in the literature, we can observe a relation of correspondence and small divergences.

The results presented in subsection 2.5, (Summary of school dropout), reveal the main reasons that interact in the student's decision to leave school. Among the results presented in the literature, in Table 2, it was highlighted a higher frequency in the student's lack of interest over other variables. This same result appeared in our field research, table 3, being corroborated by more than $80 \%$ of the teachers interviewed.

\begin{tabular}{|l|c|c|}
\hline \multicolumn{1}{|c|}{ LITERATURE } & FIELD RESEARCH \\
\hline \multicolumn{1}{|c|}{ Reasons for school dropout } & Authors & $\begin{array}{c}\text { Interviews } \\
\text { (Teachers) }\end{array}$ \\
\hline $\begin{array}{l}\text { Student Disinterest and Lack of } \\
\text { Family Support }\end{array}$ & $\begin{array}{c}\text { Barros } \text { et al. (2008), Neri (2009), Araújo and } \\
\text { Santos (2012), Mendes (2013) and Bastos (2014), }\end{array}$ & $83.3 \%$ \\
\hline Learning Difficulty & $\begin{array}{c}\text { Peixoto, Braga and Bogutchi (2003); Rumberger } \\
\text { and Lim (2008) }\end{array}$ & $66.6 \%$ \\
\hline Wrong course choice & Mattos, Neto and Bernardino (2013) & $58.3 \%$ \\
\hline Distance School x Residence & $\begin{array}{c}\text { Conceição and Zamora (2015) } \\
\text { Need to Work }\end{array}$ & $\begin{array}{c}\text { Adeleke and Ogunkola (2013); Ferreira } \\
\text { (2013); Watakabe (2015) }\end{array}$ \\
\hline
\end{tabular}

Table 3 - Correlation of the literature with the results of the research

Source: Authors

Thus, as in the literature, the results of this study pointed out the disinterest on the part of the students as the determining factor of school dropout. This, as mentioned earlier, can be attributed to the fact that these students seek only being in a good high school institution and are not interested in 
technical training, since their goal is access to college. These high school courses, because they are technical, have a length of four years and not three, as is usual in other schools. Thus, the student who only wants the high school diploma that puts him/her in conditions to compete for a place in good universities, is disappointed with the delay in his graduation, and consequently, it is demotivated.

As for the difficulty factor in learning, discussed by authors such as Peixoto, Braga and Bogutchi (2003); Rumberger and Lim (2008), it has been found that for teachers, this is also a preeminent condition. For teachers, this cause is observed in the classroom, and reverberates the condition of poor student training in their elementary school, presenting gaps in knowledge in subjects such as mathematics. Thus, it was found in this study a very substantial approximation to the data in the literature. Especially with studies of Neri (2010) and Souza (2011) pointing to social inequality as a major cause evasion.

In accordance with this aspect, another factor that shows relevant literature in the dropout process is the need to work, blaming the strong influence of this parameter the precarious socioeconomic situation in which the student falls. However, this study differed from the literature. We can infer two possibilities from this result: (1) there is no pressure to early entering in the labor market, even if these students are from lower social classes, or (2) teachers do not perceive this need (students do not share their difficulties, or there is a lack of perception of teachers/coordinators).

Considered the causes that influence the process of dropout listed in susection 2.5 , in this study, the results are similar to those found in the literature. That said, this study confirms the study of Barros et al. (2008), Neri (2009), Mendes (2013) and Bastos (2014), pointing to the lack of interest of the students, as the determining factor of dropout. However, we now have some clues about the factors hidden behind this disinterest.

\section{CONCLUSION}

This study aimed to approach the studies conducted on the subject school dropout. The concepts gathered in this second section cover dropout factors under different conceptions, where the referenced authors gave us a foundation to understand this phenomenon. Based on studies of these authors it was possible to understand important aspects that gave support the completion of this work.

The evaluation of the data showed that the abandonment occurs for various reasons. The data show that the "disinterest" factor is the most significant cause of evasion occurred in this Federal School. This factor was consolidated as there is a long period for the completion of the course, higher than most other schools, namely four years. For many students, whose school choice is based only in the quality of the high school Institution, this long stay has become a major discouragement in the permanence in the integrated high school. Teachers interviewed corroborate this argument, stating that "the period excessively long makes it unattractive and therefore demotivating".

As for learning, the difficulty in the assimilation of academic content observed in students is directly related to poor education received in the fundamental cycle. According to the teachers, there is awareness of the educational needs of these students, especially those stemmed from lower social classes and therefore it is expected that some students feel unprepared to follow the curriculum content imposed by this institution. However, curriculum and classes are not adapted to deal with this challenge. 
Regarding the prevalence of family influence, the arguments arising from interviewed teachers, allowed us to conclude that there is a great family interference, inducing young people to join a course which she/he is not identified. So, this youth is faced with school content totally adverse to what he/she expected. By adding to this the lack of basic knowledge, it causes a significant number of students express their disinterest for the course, which consequently increases the number of dropout.

Our work does not provide enough data to point alone a culprit for the failure of these students. We could not find who to blame for school failure, i.e., family, student or school infrastructure. However, as already seen in other researches, it takes the interaction of the entire system involving education: State, school, family, student and society, where everyone can understand the form of participation and thus help each other to improve conditions the publicschool system.

The results lead us to realize the absence of a policy to prevent school dropout within the researched institution. A significant loss of students shows up as a sharp weakness in serving the diverse sociocultural in the students' profile. It is noticed the lack of a specific policy for the reception of incoming protected by affirmative actions (quotas/12,711 law), since the aforementioned law only guarantees access to quality education, however, it is up to the institution to implement policies to ensure conditions of staying.

That said, we must remain alert to rapid mutations which goes to education system because, to be prepared to this new reality, we may need to abolish the old existing educational concepts. Being aware that the differences are inherent to humans, there is an urgency of curricular innovations that transform the school environment, increasing student's motivation for learning, and being able to include different profiles. It is suggested as future studies, a similar approach incorporating students who had dropped out to check for paralelisms between these responses with those of teachers participating in this research.

\section{REFERENCES}

ADELEKE, A. I.; OGUNKOLA, E. O. The Effects of Dropout Syndrome on Child and the Society. The Social Sciences, v. 8, n. 2, p. 172-179, jul, 2013.

ARANHA, A. A escola que os jovens merecem. Revista Época. São Paulo, n. 587, ago. 2009.

ARAÚJO, C. F.; SANTOS, R. A. A educação profissional de nível médio e os fatores internos/externos às instituições que causam a evasão escolar. In: The 4th International Congress on University- Industry Cooperation, Taubaté, São Paulo, 05-07, dez, 2012. Disponível em: 〈http://www.unitau.br/unindu/artigos/pdf525.pdf>. Acesso em 20 jul. 2015.

ARCHAMBAULT, Isabelle et al. Individual, social, and family factors associated with high school dropout among lowSES youth: Differential effects as a function of immigrant status. British Journal of Educational Psychology, 2017.

AZEVEDO, F. V. M. de. Causas e consequências da evasão escolar no ensino de jovens e adultos na Escola Municipal "Espedito Alves". FAL-Rio Grande do Norte, Angicos, v. 2, n. 13, p. 31-38, mai, 2006.

BARRETO, Simone Rodrigues; DO CARMO, Gerson Tavares. REFLEXÕES ACERCA DA MIDIATIZAÇÃO DA EVASÃO E PERMANÊNCIA ESCOLAR NO BRASIL E MÉXICO. In: Congresso Latino Americano de Humanidades. 2017.

BARROS, R. P.; CARVALHO, M.; FANDINHO, M.; FRANCO, S. Abandono e evasão no ensino médio no Brasil: magnitudes e tendências, in Coletânea de artigos produzidos para o seminário A Crise de Audiência do Ensino Médio realizado em 4 e 5 de dezembro de 2008, São Paulo. Disponível em <http://ww2.itau.com.br/institutounibanco/pdf/Seminarios-do-InstitutoUnibanco/18.pdf>. Acesso em: 27 jul. 2015. 
BASTOS, O. G. A. A evasão escolar no Ensino Técnico: entendendo e enfrentando as dificuldades - Um estudo de caso do CEFET-RJ. 2014. 112 f. Dissertação (Mestrado Profissional em Sistemas de Gestão) Universidade Federal Fluminense, Niterói, 2014.

BATISTA, S. D.; SOUZA, A. M.; OLIVEIRA, J. M. S. A evasão escolar no ensino médio: um estudo de caso. Revista Profissão Docente, Uberaba, v.9, n.19, p. 70-94, jan/jul. 2009.

BRANDÃO, Z.; BIANCHINI, A. M.; ROCHA, A. D. C. O estado da arte da pesquisa sobre evasão e repetência no ensino de $1^{\circ}$ grau no Brasil. Revista Brasileira de Estudos Pedagógicos, Brasília, v. 64, n. 147, p. 38-69, maio/ago.1983.

BRASIL. Instituto Nacional de Estudos e Pesquisas Educacionais Anísio Teixeira - INEP. Censo Escolar de 2013. Brasília, 2014. Disponível em: <http://portal.inep.gov.br/resumos-tecnicos> Acesso em: 19 jul. 2015.

BRASIL. Sistema de Indicadores de Percepção Social (SIPS) / Organizador: Fábio Schiavinatto. - 1 ed. - Brasília : Ipea, 2011. 254 p. Disponível em: <ww.ipea.gov.br/portal/index.php?option=com_content\&view>. Acesso em: 16 jul. 2015.

BRASIL. Constituição da República Federativa do Brasil. Brasília, DF: Senado Federal: Centro Gráfico, 1988. 292 p.

BRASIL. Estatuto da criança e do adolescente. Lei federal no 8069, de 13 de julho de 1990. 12. ed. Brasília : Câmara dos Deputados, Edições Câmara, 2014. Disponível em: <http://www2.camara.leg.br/responsabilidadesocial/acessibilidade/legislacao-pdf/estatuto-da-crianca-e-do-adolescente>. Acesso em: 19 jul. 2015.

BRASIL. Lei de Diretrizes e Bases da Educação Nacional, Lei federal n o 9.394, de 20 de dezembro de 1996. Brasília: Presidência da República, Casa Civil, Subchefia para assuntos jurídicos, 1996. 46 p. Disponível em: <http://www2.camara.leg.br/documentos-e-pesquisa/publicacoes/edicoes/paginas-individuais-dos-livros/lei-dediretrizes-e-bases-da-educacao-nacional>. Acesso em: 19 jul. 2015.

DORE, Rosemary; LUSCHER, Ana Zuleima. Permanência e evasão na educação técnica de nível médio em Minas Gerais. Cad. Pesqui., São Paulo, v. 41, n. 144, p. 770-789, Dec. 2011.

FERREIRA, L. A. M. Evasão escolar. 2013. Disponível em: 〈http://www.mpsp.gov.br/portal/page>. Acesso em: 21 jul. 2015.

GARCIA, Antonio R. et al. Patterns of Multisystem Service Use and School Dropout Among Seventh-, Eighth-, and Ninth-Grade Students. The Journal of Early Adolescence, p. 0272431617714329, 2017.

GIL, A. C. Como elaborar projetos de pesquisa. 5. ed. São Paulo: Atlas, 2010. 184 p.

GOTTFRIED, Michael A.; PLASMAN, Jay Stratte. Linking the Timing of Career and Technical Education Coursetaking With High School Dropout and College-Going Behavior. American Educational Research Journal, p. $0002831217734805,2017$.

JIMÉNEZ ASENJO, W.; GAETE ASTICA, M. Estudio de la exclusión educativa y abandono en la enseñanza secundaria en algunas instituciones públicas de Costa Rica. Revista Electrónica Educare, v.17, n.1, p.105-128, 2013.

KALLEBERG, A. L. Good jobs, bad jobs. New York, NY: Russell Sage Foundation, 2011. 312 p.

LANSFORD, Jennifer E. et al. A public health perspective on school dropout and adult outcomes: a prospective study of risk and protective factors from age 5 to 27 years. Journal of Adolescent Health, v. 58, n. 6, p. 652-658, 2016

LEON, F. L. L., MENEZES-FILHO, N. A. Reprovação, avanço e evasão escolar no Brasil. Pesquisa e Planejamento Econômico, Rio de Janeiro, v. 32, n.3, p. 417-452, dez, 2002

LIMA, Ricardo Rodrigues Dias et al. Aplicação do método multicritério AHP na observação dos motivos da evasão escolar. In: Proceedings of International Conference on Engineering and Computer Education. 2016. p. 52-54.

LÜSCHER, A. Z.; DORE, R. Política educacional no Brasil: educação técnica e abandono escolar. Revista Brasileira de Pós - Graduação, Brasília, v. 8, n.1, p. 147-176, dez, 2011.

MACHADO, M. R. A evasão nos cursos de agropecuária e informática / Nível técnico da Escola Agrotécnica Federal de Inconfidentes/MG (2002 a 2006). 2009. 131 f. Dissertação de Mestrado. Faculdade de Educação da UNB: Brasília, DF, 2009.

MARCONI, M. A.; LAKATOS, E. M. Fundamentos de metodologia científica. 7. ed. SÃO PAULO: Atlas, 2010. 297 p. 
MENDES, M. S. Da inclusão à evasão escolar: o papel da motivação no ensino médio. Revista Estudos de Psicologia, Campinas, v. 30, n. 2, p. 261-265, abr/jun, 2013.

NERI, M. C. A Educação profissional e você no mercado de trabalho. Instituto Votorantim Rio de Janeiro. FGV/CPS, 2010.

NERI, M. C. Motivos da evasão escolar. Brasília: Fundação Getulio Vargas, 2009.

Programa das Nações Unidas para o Desenvolvimento (PNUD, 2013) - Material de Apoio: Perguntas Frequentes Desenvolvimento Humano, IDH e IDHM - Disponível em: <http://www.pnud.org.br/arquivos/faq-atlas2013.pdf>. Acesso em: 22 jul. 2015.

Programa das Nações Unidas para o Desenvolvimento (PNUD, 2014) - Relatório de Desenvolvimento Humano 2014. Disponível em: < http://hdr.undp.org>. Acesso em: 01 jul. 2015.

Programa Nacional de Amostra Domiciliar (PNAD, 2013): Primeiras Análises. Disponível em: <http://www.ibge.gov.br/home/estatistica/pesquisas/pesquisa_resultados.php?idpesquisa=149>. Acesso em: 22 jul. 2015.

SANTOS, Celso Ubirajara Soares; VIANNA, Patricia Duro; BULHOSA, Fabio Andrade. O Fracasso Escolar entre Estudantes do $6^{\circ}$ Ano de Escolas Públicas Estaduais de Rio Grande, RS. Revista de Ensino, Educação e Ciências Humanas, v. 17, n. 2, p. 126-131, 2016.

SEVERINO, D.; DIAS, L. Evasão nos cursos presenciais do Insituto Federal de Educação, Ciência e Tecnologia do Triângulo Mineiro, Campus Uberlândia. Anais do III Colóquio Internacional sobre a Educação Profissional e a $\begin{array}{llll}\text { Evasão } & \text { Escolar, } & 2013 . & \text { Disponível }\end{array}$ <https://docs.google.com/document/d/19zSVdeDEu2t4uD6U7FtPI7DwCQYFZGQGBbpCL20XHM 8/edit>. Acesso em 15 jul. 2015.

SOUZA, A. de M. A Relevância dos Indicadores Educacionais para Educação Básica: informação e decisões. Revista Meta: Avaliação. Rio de Janeiro, v. 2, n. 5, pp.153-179, mai./ago, 2010.

WATAKABE, T. A evasão escolar dos alunos cotistas sociais na educação profissional. Revista Espaço Acadêmico, Paraná, v.15, n.170, p. 87-98, out, 2015.

YI, H.; Zhang, L.; YAO, Y.; WANG, A.; MA, Y.; SHI, Y.; CHU, J.; PRASHANT, L.; ROZELLE, S. Exploring the dropout rates and causes of dropout in upper-secondary technical and vocational education and training (TVET) schools in China. International Journal of Educational Development, v. 42, p. 115-123, may, 2015.



This work is licensed under a Creative Commons Attribution 4.0 International License. 